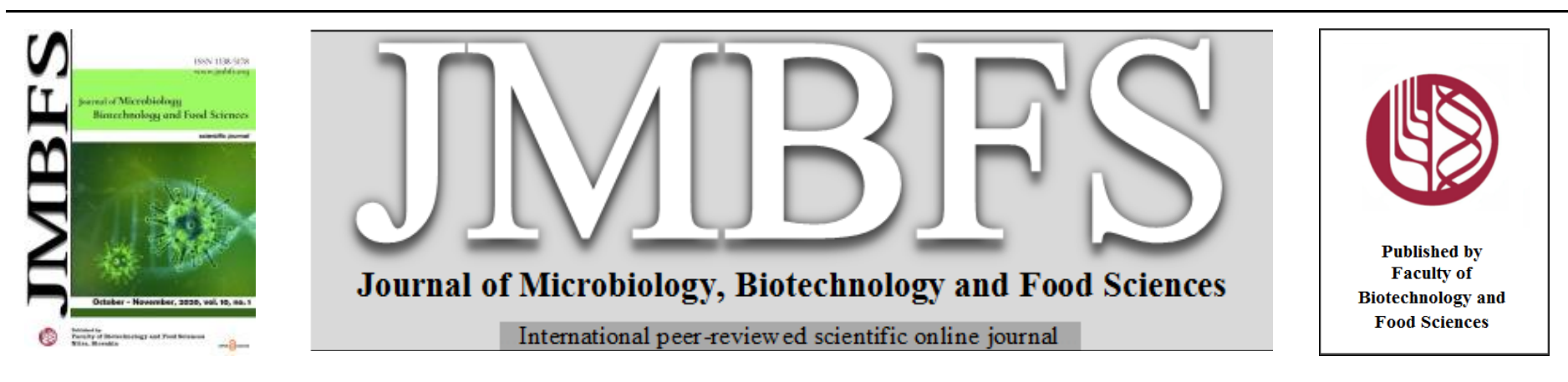

\title{
SEED GERMINATION AND MICROPROPAGATION STUDIES OF MAMMEA SURIGA KOSTERM
}

\author{
Sudhesh Shastri, Krishna Venkatarangaiah*, Ajith Sheshagiri
}

Address(es):

Department of Biotechnology, Kuvempu University, Shankaraghatta, Shimoga-577 451, Karnataka, India.

*Corresponding author: krishnabiotech2003@gmail.com

doi: 10.15414/jmbfs.2020.10.2.211-216

ARTICLE INFO

Received 18. 12. 2019

Revised 7. 6. 2020

Accepted 12. 6. 2020

Published 1. 10. 2020

Regular article

OPEN $\partial_{\text {ACCESS }}$

\begin{abstract}
Mammea suriga Kosterm. is a RET species distributed in Malnad region of the Western Ghats, which is over exploited for flowers, seeds and timbers, hence the population is declined. The study was conducted to evaluate the germination potency of the seeds in both in vivo and in vitro conditions to derive a regeneration protocol for the ex situ conservation. Among the pre-treated seeds, the decoated seeds pre-treated with $0.5 \mathrm{mg} \mathrm{L}^{-1} \mathrm{NAA}$ for $24 \mathrm{~h}$ resulted in $86 \%$ of germination. In in vitro condition, culture of decoated seeds on MS medium supplemented with $0.5 \mathrm{mg} \mathrm{L}^{-1} \mathrm{NAA}$ and $0.1 \mathrm{mg} \mathrm{L}^{-1} \mathrm{TDZ}$ resulted $91.67 \%$ of germination. Micropropagation studies showed that the interaction of 2-3 mg L $\mathrm{L}^{-1} \mathrm{BAP}$ and $0.2 \mathrm{mg} \mathrm{L}^{-1} \mathrm{TDZ}$ induced multiple shoots from cotyledonary and hypocotyl explants. Mass of callus induced from the leaf explants at the concentration of $1 \mathrm{mg} \mathrm{L}^{-1}$ 2,4-D and $3 \mathrm{mg} \mathrm{L}^{-1}$ BAP. Later on the photosynthetic callus, organise in to shoot buds at the concentration of $3 \mathrm{mg} \mathrm{L}^{-1} \mathrm{BAP}$ and $0.2 \mathrm{mg} \mathrm{L}^{-1} \mathrm{TDZ}$. The excised micro shoots showed rhizogenesis on the media fortified with $1.5 \mathrm{mg} \mathrm{L}^{-1} \mathrm{IBA}$. The regenerants derived from both direct and indirect organogenesis exhibited similar morphological features.
\end{abstract}

Keywords: Mammea suriga, seed germination, micropropagation

\section{INTRODUCTION}

Plants are valuable sources of medicinal and many other pharmaceutical products. The conventional methods of propagation take a long time for multiplication because of a low rate of fruit set, along with poor germination. The plants used in the phyto-pharmaceutical preparations are obtained mainly from the natural growing areas. With the increase in the demand for the drugs, the plants are being overexploited, threatening the survival of many rare species. Also, many medicinal plant species are disappearing at an alarming rate due to depletion of habitat, rapid agricultural and urban development, uncontrolled deforestation, and indiscriminate collection. Advanced biotechnological methods of culturing plant cells and tissues should provide new means for conserving medicinal plants. The use of controlled environments in these techniques can overcome cultivation difficulties and could be a means to manipulate phenotypic variation in bioactive compounds and toxins (Pradeepa, 2016; Venkatesh, 2017; Santhosh Kumar, 2017). Therefore, standardisation of micropropagation protocol and ex situ conservation of threatened and endangered medicinal plant species is of utmost importance.

Mammea suriga is found in evergreen forests of western India from Khandala southwards to Malabar and Coimbatore (Pullaiah, 2006), cultivated in Assam, West Bengal, Orissa and Uttar Pradesh (pilikula.com/botanical_list/botanical_name_m/mammea_suriga.html). It is also found in Ceylon and West Indies (Chopra 1956). Mammea suriga Kosterm. belongs to the family Calophyllaceae. It is a medium-sized tree bearing fragrant white flowers. It is commonly called as Indian rose chestnut or Ceylon ironwood and vernacularly called as Punnag (Sanskrit), Surangi (Hindi), Suragi (Kannada) etc. (http://en.wikipedia.org/wiki/Mammea_suriga). Leaves are simple, opposite, thickly coriaceous, dark green, base rounded, midrib stout prominent, veins few, indistinct, very slender, and beautiful. Androdioecious tree speciesmale flowers on one plant and either female or bisexual flowers on other plants. The flowers cauliflorous- born on old stem during hot season, (http://indiabiodiversity.org/species/show/14963), sprouts as beautifully rounded buds, which bloom into four-petaled white flowers. The flowers are extremely fragrant, chiropterophilous, and its powerful scent can hit the nostrils even from a long distance. Fruit ripens during rainy season, and it is obliquely ovoid, 1-seeded. It is also reported that some of the fruits of this species have double seeds. Moreover, they have quantified rate of double seeds among different individuals within a population. (flowersofindia.net/catalog/slides/Surangi.html). Due to handsome foliage and sweetly scented flowers, this plant is used in avenue planting program. Fresh flowers of the tree are used for worshipping in temples as well as in personal adornment. In the local floral market per $\mathrm{kg}$ of flower buds costs 150-200 Rupees. The dry flowers maintain fragrance for long time; therefore, flowers are used in perfumery industries. The silky red dye extracted from dried flower is used in textile industries. The flower bud has medicinal properties and used as astringent as well as in dyspepsia. Hence, this species is considered as multipurpose tree species of Western Ghats (Smita, 2013). In traditional medicine, flower buds are mainly used for skin eruption, itching, small tumours, blood and heart troubles, sore throat, cough, vomiting, dysentery, bleeding piles, for fevers, foul breath. It is also used as mild stimulant, adulterants, carminative and astringent properties and is used in dyspepsia (Pullaiah, 2006). The root bark showed antimalarial activity (Valsaraj $\boldsymbol{e t}$ al., 1995) and used to cure leprosy, eczema and other skin diseases (Prusti and Behera, 2007). This species is very sparsely found in the forests of North Canara of the Western Ghats and as per CAMP (2001), IUCN RED List (2007) and ADMA RED list, Mammea suriga Kosterm. is reported as a threatened tree species endemic to the Western Ghats (Ankur and Vasudeva, 2003). In this investigation, we report the protocol for the enhancement of germination potency of the seeds in both in vivo and in vitro conditions to derive a regeneration protocol for the ex-situ conservation of this threatened species. 

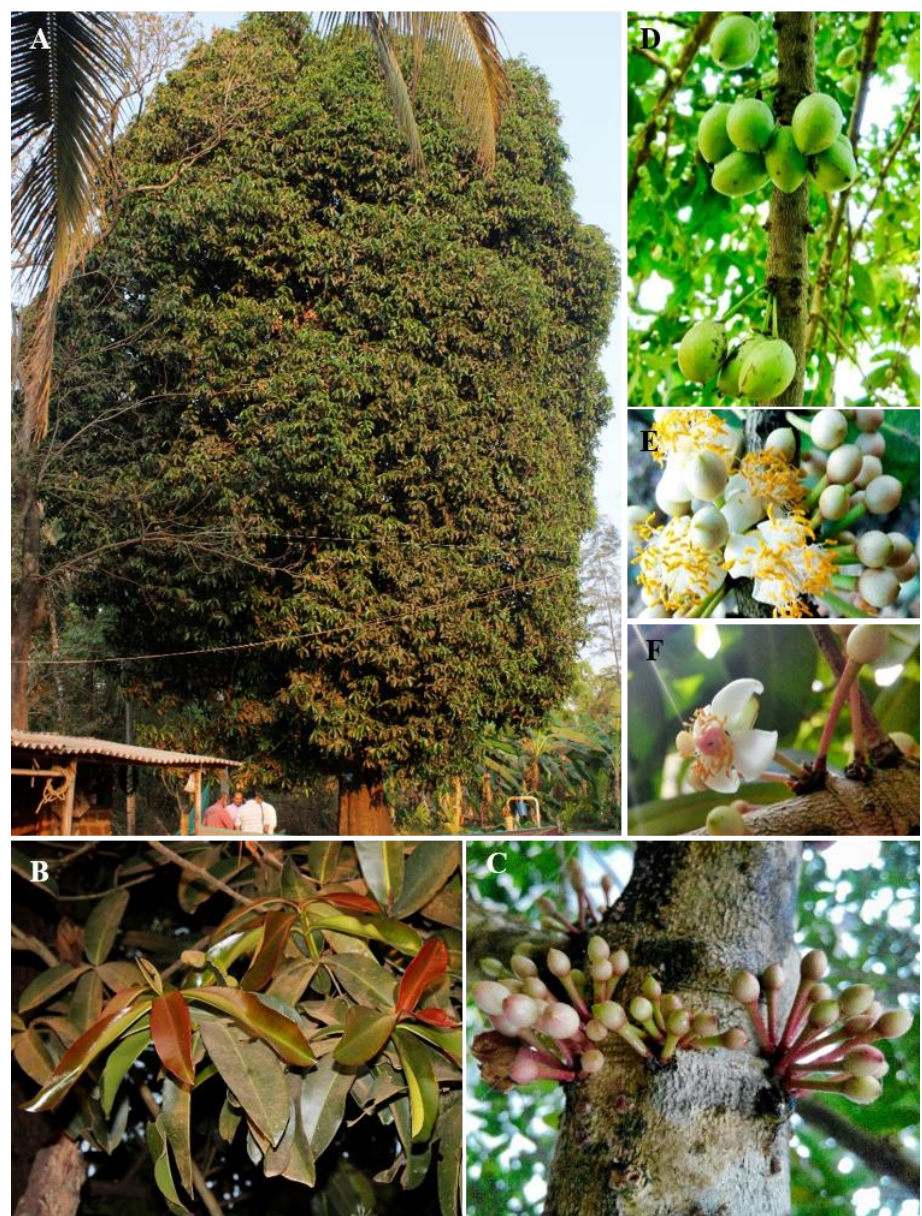

Figure 1 Mammea suriga Kosterm.

Legend:A: Habitat, B: Foliage, C: Inflorescence, D: Fruit insertion, E: Male flower, F: Bisexual flower.

\section{MATERIALS AND METHODS}

\section{Seed germination studies}

Mammea suriga immature seeds were collected from a healthily grown tee in May. For in vivo germination studies before use, unsterilized seeds were subjected to various pre-treatments, viz. soaking in water for $48 \mathrm{~h}, 0.1 \% \mathrm{KNO}_{3}$, $0.5 \mathrm{mg} \mathrm{L}^{-1} \mathrm{NAA}$ treatment for $24 \mathrm{~h}$, decoated seeds, decoated seeds pre-treated with $0.5 \mathrm{mg} \mathrm{L}^{-1} \mathrm{NAA}$ for $24 \mathrm{~h}$. The seeds were washed with tap water to remove traces of chemicals and were sown directly in the soil at a depth of $3 \mathrm{~cm}$ in a tray. Watering was done every day. Germination of the seeds was tested in room temperature; seeds were sown in replications containing 100 seeds each. The observations on germination were recorded.

For in vitro germination studies the seeds were sterilised prior to use with running tap water followed by, tween 20 and with $70 \%$ ethanol, finally sterilised with $1 \%$ mercuric chloride and washed three times with sterile water. Seed coat was removed and inoculated in MS medium supplemented with 2 to $5 \mathrm{mg} \mathrm{L}^{-1}$ of BAP and 0.1 to $0.5 \mathrm{mg} \mathrm{L}^{-1}$ of TDZ for germination. Cultures were incubated under fluorescent lights at $25^{\circ} \mathrm{C}$, the humidity was maintained at $85 \%$ under a photoperiod of $16 \mathrm{~h}$ of light $\left(25 \mu \mathrm{mol} \mathrm{s} \mathrm{s}^{-1}\right)$, and eight-hour dark. The experiments were done in replicates and incubated in room temperature in light and dark conditions. The progress of the germination was recorded and analysed as per the investigation of Rajesh et al., 2011 and Ajith et al. 2018. The data of three independent experiments were statistically analysed using ezANOVA 3.0 and represented in Mean $\pm \mathrm{SE}$

\section{Micropropagation}

\section{Plant material and explant sterilisation}

The cotyledon, hypocotyl and tender leaves were used as explants. The explants were thoroughly washed with tap water using a soft brush to remove dust and soil particles. It was kept under running tap water for 5-10 minutes and later the explants were treated with Bavistin (along with 2-3 drops of Tween-20) for 30 minutes, washed thrice with autoclaved water and then treated with $1 \%$ tween 20 for $5 \mathrm{~min}$, washed with autoclaved water thrice, followed by $70 \%$ ethanol wash for $1 \mathrm{~min}$ further the explant is washed with $0.6 \%$ sodium hypochlorite for 15 min, washed with autoclaved water thrice. The explants were further sterilised inside LAF chamber starting with one water wash followed by, $0.1 \%$ mercuric chloride for 4-5 minutes and finally three water washes for 5 minutes each. The explants were drained off from the water by keeping them in sterile petri plates for 10 minutes near the hood blower. The explants were then trimmed all around and were cut into six $\mathrm{mm}^{2}$ and inoculated onto the medium (Sigma protocol. Explant Sterilization - Plant Tissue Culture Protocol, 1999; Yen and Hain, 2012; Oluwakemi et al. 2018).

\section{Direct organogenesis}

The effect of auxins and cytokinins were evaluated on direct organogenesis from the explants. The cotyledon and hypocotyl explants were inoculated onto MS media supplemented with different concentrations and combinations of BAP (1 to $\left.4 \mathrm{mg} \mathrm{L}^{-1}\right)$ with TDZ (0.1 to $\left.0.5 \mathrm{mg} \mathrm{L}^{-1}\right)$.

\section{Indirect organogenesis}

Tender leaf explants were cultured on MS media fortified with different concentrations and combinations of 2, 4-D (0.5 to $\left.2 \mathrm{mg} \mathrm{L}^{-1}\right)$ with BAP (1 to $5 \mathrm{mg}$ $\mathrm{L}^{-1}$ ) for the induction of callogenesis from the explants. The shoot differentiating media consisted of 1 to $4 \mathrm{mg} \mathrm{L}^{-1} \mathrm{BAP}$ and 0.1 to $0.5 \mathrm{mg} \mathrm{L}^{-1} \mathrm{TDZ}$.

In all the experiments, cultures were incubated under fluorescent lights at $25^{\circ} \mathrm{C}$, the humidity was maintained at $85 \%$ under a photoperiod of $16 \mathrm{~h}$ of light $(25$ $\mu \mathrm{mol} \mathrm{s}{ }^{-1} \mathrm{~m}^{-1}$ ), and eight-hour dark, and the cultures were monitored daily. In all the above experiments, after observing callus induction, multiplication of callus and shoot proliferation, the cultures were allowed to grow further. Subsequently, multiple shoots formed were dissected into individuals and sub cultured on to the same MS media. Shoots with at least 2-4 well-developed leaves were transferred for rooting. After 20-40 days of incubation, induction of shoot organogenesis in terms of a number of shoots per explants was recorded and statistically analysed using ezANOVA 3.0 and represented as mean $\pm \mathrm{SD}$.

\section{Rooting and acclimatisation}

Healthy shoots with minimum 4-6 leaves were transferred to MS medium with 2 $\mathrm{mg} \mathrm{L}^{-1}$ IBA for a root formation. Root formation was evaluated after 15 days. Further plantlets were allowed to grow for another 14-15 days. Well-developed plantlets were transferred to seed trays containing a mixture of vermiculite and sand in equal ratio and humidity is maintained for further growth of plantlets by covering the plantlets with a polythene bag. Further, the well-grown plantlets were transferred to pots with gardening soil for secondary hardening.

\section{RESULTS}

\section{Micropropagation of Mammea suriga}

\section{In vivo seed germination}

Initially, experiment was conducted to evaluate the germination potency of Mammea suriga seeds in the in vivo condition. Seeds are soaked in water for $48 \mathrm{~h}$ and then sown in sterilised soil bed. Commencement of seed germination was noticed after 42 days, and only $20 \%$ of the seeds were germinated. In pretreatment with $0.1 \% \mathrm{KNO}_{3}$ and $0.5 \mathrm{mg} \mathrm{L}^{-1} \mathrm{NAA}$ for $24 \mathrm{~h}$ only $38 \%$ and $46 \%$ respectively, of intact seeds were germinated. Germination noticed after 30 days. Whereas, the percentage of germination was enhanced to $72 \%$ in the decoated seeds and seed germination was observed after 30 days. The decoated seeds pretreated with $0.5 \mathrm{mg} \mathrm{L}^{-1} \mathrm{NAA}$ for $24 \mathrm{~h}$ resulted in $86 \%$ of germination, and the percentage data is shown in figure 2 .

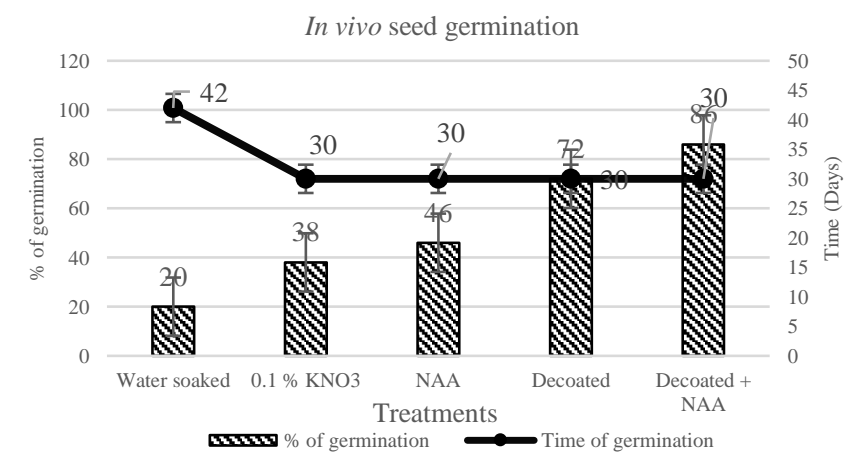

Figure 2 Percentage of seed germination in vivo condition

Legend: The $\mathrm{X}$-axis represents treatments, and the $\mathrm{Y}$-axis represents the percent of germination of seeds, the bars represent Mean \pm SE. 


\section{In vitro seed germination}

Commencement of seed germination was started after 15 days of incubation, and the percentage of seed germination was enhanced to $91.67 \%$ after 30 days of incubation (figure 3).

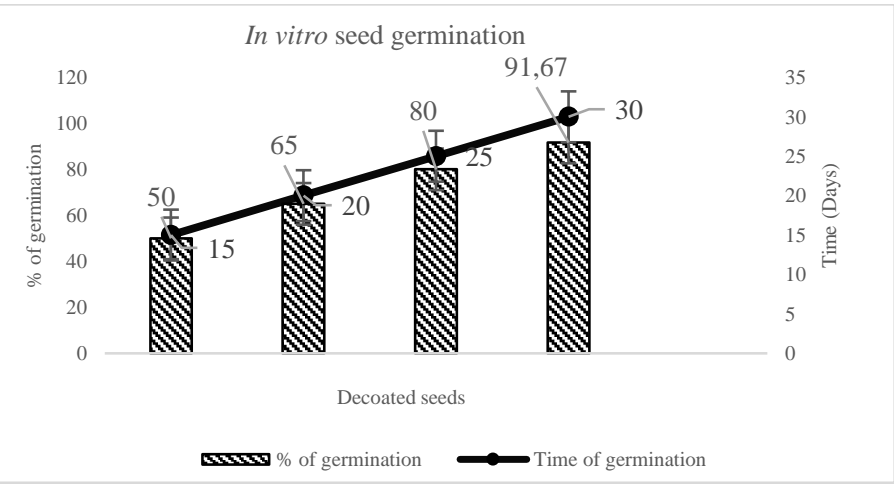

Figure 3 Seed germination in in vitro condition on MS media

Legend: The $\mathrm{X}$-axis represents treatments and the $\mathrm{Y}$-axis represents time (days) of germination of seeds, the bars represent Mean \pm SE.

\section{Micropropagation studies}

\section{Direct organogenesis}

The in vitro shoot regeneration was noticed directly from the cotyledon and hypocotyl explants in the combinations of BAP $\left(3 \mathrm{mg} \mathrm{L}^{-1}\right)$ and TDZ $\left(0.2 \mathrm{mg} \mathrm{L}^{-1}\right)$ (Table 1) without undergoing callogenic phase. In cotyledon explant culture, multiple shoot organogenesis was found to be the best at a concentration of $2 \mathrm{mg}$ $\mathrm{L}^{-1}$ BAP and $0.2 \mathrm{mg} \mathrm{L^{-1 }}$ TDZ. Before shoot organogenesis, growth and enlargement of cotyledonary explant were noticed. After three weeks of culture, the explant became photosynthetic, and organogenesis of multiple shoots was noticed from the cotyledonary node of the explant. In hypocotyl, explant culture organogenesis of shoots noticed from the nodes and the excised end of the explants. At the concentration of $3 \mathrm{mg} \mathrm{L}^{-1}$ BAP and $0.2 \mathrm{mg} \mathrm{L}^{-1} \mathrm{TDZ}, 1.67 \pm 0.58$ shoots were organised from the hypocotyl explants. Within a week of incubation elongation of the excised explants were noticed. Before initiation of the shoot, bud's nodal region became swollen and sprouting of shoot buds were noticed after 4 weeks of culture. The organised shoots grew up with photosynthetic leaf primordia.

After 6 weeks of culture, the well-grown micro shoots with 2-3 leaves were excised aseptically and sub cultured on to rooting media supplemented with 0.5 to $4 \mathrm{mg} \mathrm{L}^{-1}$ IBA. At a concentration of $1.5 \mathrm{mg} \mathrm{L}^{-1}$ IBA rhizogenesis noticed from the basal node of the micro shoots. The well-rooted plants were isolated, media attached to which was cleaned and transferred to pots containing a mixture of vermiculite and sand in equal proportion. The plantlets were initially hardened in the culture room by covering with a polythene bag to maintain the humidity; later secondary hardening was carried out in the greenhouse condition (figure 4).

Table 1 Effect of interaction of BAP and TDZ on caulogenesis from the cotyledon and hypocotyl explants

\begin{tabular}{lcc}
$\begin{array}{l}\text { Growth regulators }\left(\mathrm{mg} \mathrm{L}^{-1}\right) \\
\text { BAP }\end{array}$ & $\begin{array}{c}\text { No. of shoot buds } \\
\text { Organised }\end{array}$ \\
\hline
\end{tabular}

\begin{tabular}{lcc} 
BAP & TDZ & Organised \\
\hline & Cotyledon explants & \\
\hline 1 & 0.1 & 0 \\
1 & 0.2 & 0 \\
1 & 0.5 & 0 \\
2 & 0.1 & $1.33 \pm 0.58$ \\
2 & 0.2 & $2.67 \pm 0.58$ \\
2 & 0.5 & $0.67 \pm 0.58$ \\
2.5 & 0.1 & 0 \\
2.5 & 0.2 & 0 \\
2.5 & 0.5 & 0 \\
\hline & Hypocotyl explants & 0 \\
\hline 1 & 0.1 & 0 \\
1 & 0.2 & 0 \\
2 & 0.1 & $0.50 \pm 0.71$ \\
2 & 0.2 & $1.0 \pm 0.0$ \\
3 & 0.1 & $1.67 \pm 0.58$ \\
3 & 0.2 & 0 \\
4 & 0.1 & 0.0 \\
4 & 0.2 &
\end{tabular}

Legend: The values consist of Mean $\pm \mathrm{SD}$ of three independent experiments

\section{Indirect organogenesis}

\section{Leaf explant culture}

The leaf explant of $M$. suriga inoculated onto MS medium augmented with a range of 0.5 to $2.0 \mathrm{mg} \mathrm{L}^{-1} 2,4-\mathrm{D}$, and 1 to $5.0 \mathrm{mg} \mathrm{L}^{-1} \mathrm{BAP}$ showed callogenesis has shown in figure 5 and table 2. Callus was first initiated from the midvein of the excised leaf disc. Later the whitish mass of callus was spread over the excised end and dorsal surface of the leaf explant. The primary callus was whitish hard nodular compact mass. Luxuriant callus proliferation was noticed after sub culturing on the same medium. On shoot, differentiating media fortified with 2 to $4 \mathrm{mg} \mathrm{L}{ }^{-1} \mathrm{BAP}$ and 0.1 to $0.5 \mathrm{TDZ}$. The whitish mass of callus turned to brown and became hard and nodular. The initiation and differentiation of shoot buds from the leaf callus mass were noticed at a concentration of $3 \mathrm{mg} \mathrm{L}^{-1} \mathrm{BAP}$ and $0.2 \mathrm{mg} \mathrm{\textrm {L } ^ { - 1 }}$ TDZ. As compared to juvenile explant cultures, the caulogenic efficacy was found to be less in leaf explant culture. Only one or two shoots grew up from each mass of callus. The well-grown leaf callus regenerated micro shoots were transferred to rooting media supplemented with $1.5 \mathrm{mg} \mathrm{L}^{-1}$ IBA. As observed in the case of cotyledonary culture, the leaf calli regenerated shoots were also showed the organogenesis of the roots from the basal nodes. However, the frequency of rhizogenesis was found to be less. The well-grown leaf calli regenerated plants were subjected to primary hardening, secondary hardening and transferred to pots containing the garden soil. The morphology of the 6 months old leaf calli regenerated plant was found to be similar to the plants of direct organogenesis from cotyledonary and hypocotyl explants.

Table 2 Effect of growth regulators on leaf explant culture

\begin{tabular}{llc}
\hline Growth regulators $\left(\mathrm{mg} \mathrm{L}^{\mathbf{1}}\right)$ & BAP & No. of shoot buds/callus \\
$\mathbf{2 , 4 - D}$ & 1 & 0 \\
\hline 1 & 1.5 & 0 \\
1.5 & 2 & 0 \\
2 & 1 & 0 \\
1.5 & 2 & $1.0 \pm 0.0$ \\
1 & 3 & $1.67 \pm 0.58$ \\
1 & 2.5 & 0 \\
0.5 & 5 & $1.0 \pm 0.0$ \\
0.5 & 5 & \\
\hline
\end{tabular}

Legend: The values consist of Mean $\pm \mathrm{SD}$ of three independent experiments
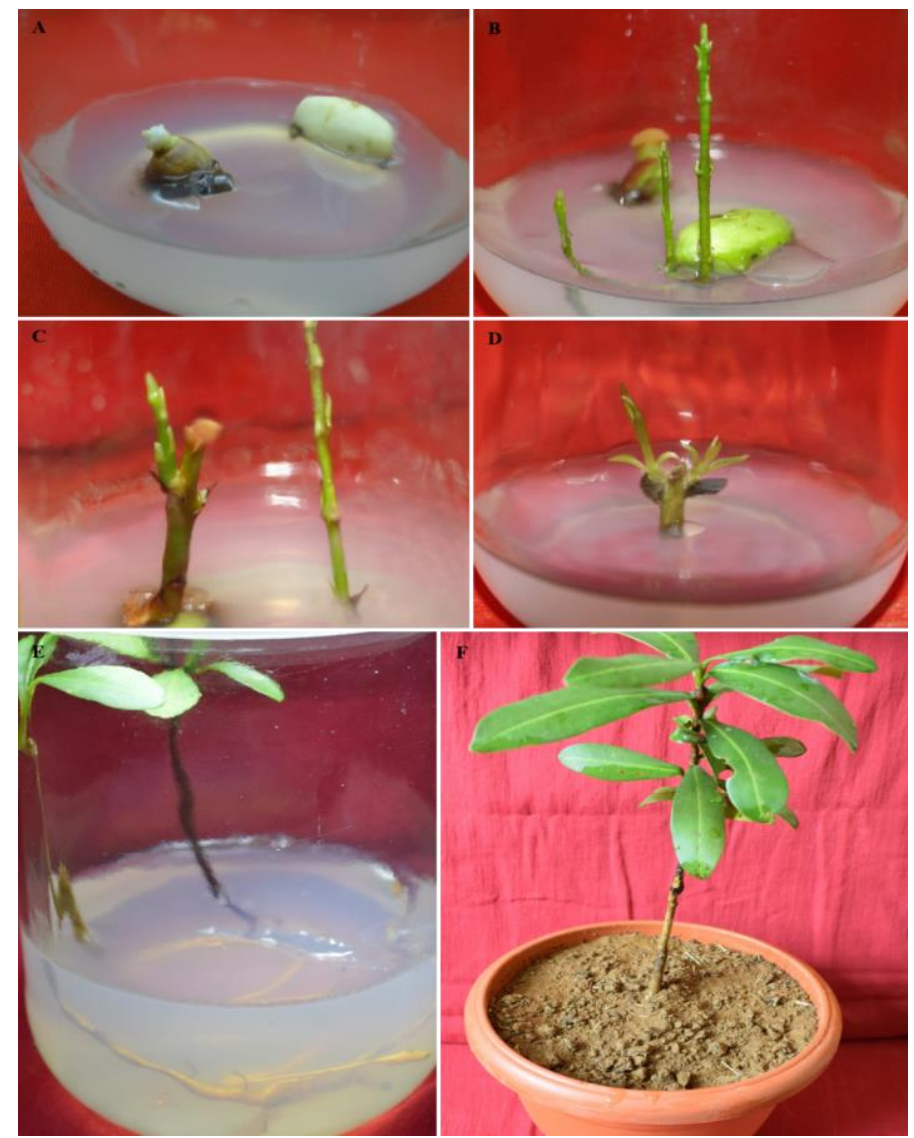

Figure 4 Regeneration of plantlets from hypocotyl and cotyledonary explants of M. suriga on MS media.

Legend: A \& B: Shoot bud organogenesis from the nodes of hypocotyl explants on MS media fortified with $3 \mathrm{mg} \mathrm{L}^{-1} \mathrm{BAP}$ and $0.2 \mathrm{mg} \mathrm{L}^{-1} \mathrm{TDZ}, \mathrm{C} \& \mathrm{D}$ : Organized growth of multiple shoots from cotyledonary explant, E: Rhizogenesis from the base of the micro shoot, F: One-month-old potted plantlet. 


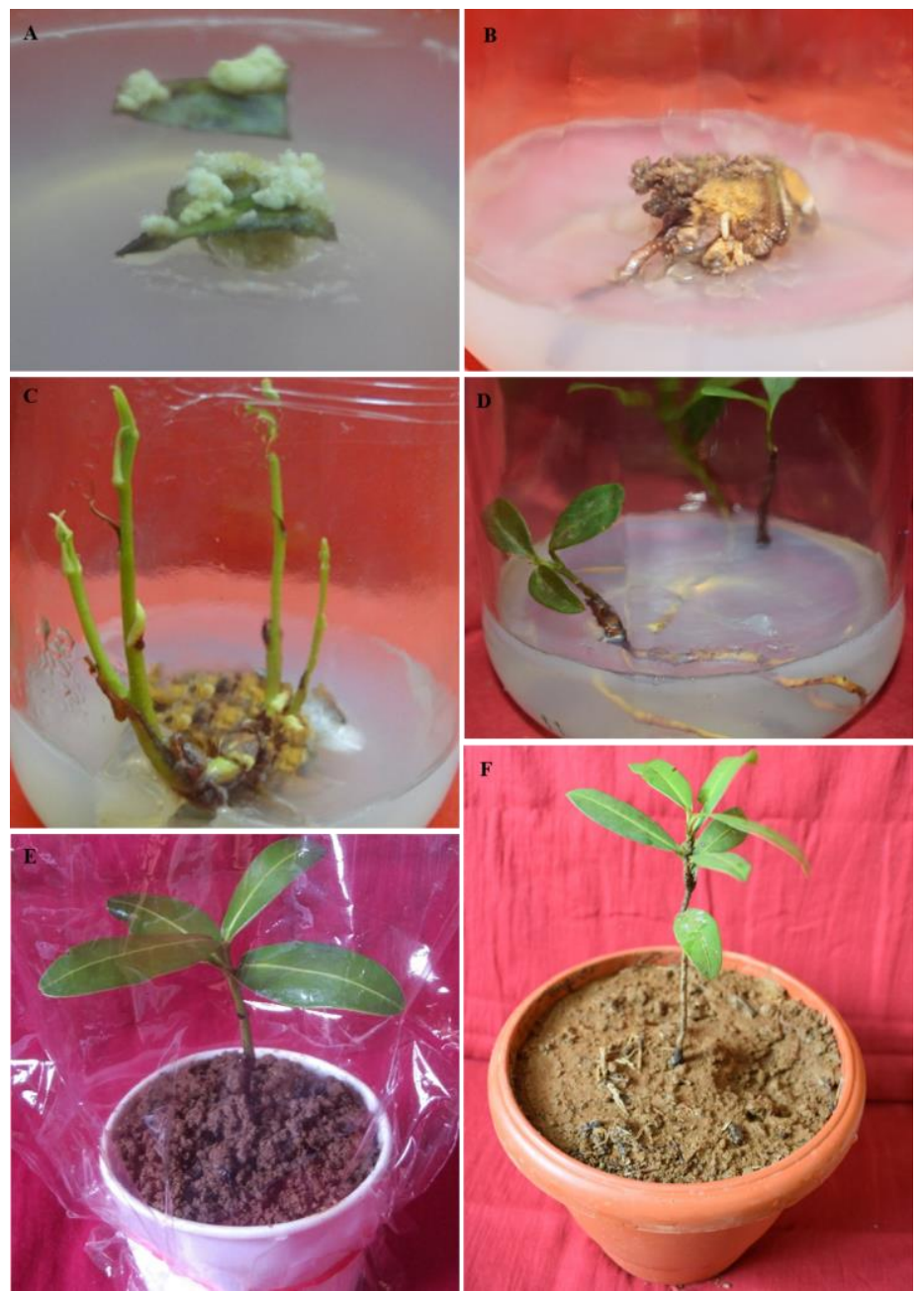

Figure 5 Indirect regeneration of plants from leaf explant

Legend: A \& B: Initiation of callus from leaf explant, C: Formation of multiple shoots, D Rooting of subcultured shoots, E \& F: Acclimatization of regenerated plants

\section{DISCUSSION}

\section{In vivo and in vitro seed germination}

The ultimate role of seeds is to produce offspring and maintain species. Most of the seeds will sprout and grow with no more boost than contact with moist soil, while others, particularly woody plants, remain dormant until the right time to germinate. In the environment, physical and chemical factors trigger and stimulates dormant seeds when their time has come. Under a gardener's care, seeds are carefully stored under controlled conditions so that, they never encounter the influence of seasons, light, temperatures and other factors that tell them it's time to germinate, so they remain dormant, and seeds are incapable of germinating because of some inhibitory factor(s). Such seeds even placed under suitable environments of germination are unable to germinate. This is called the process of seed dormancy. Sometimes the seeds are quiescent. Such seeds do not germinate because of the lack of favourable environmental conditions. These seeds need special treatment to trick them into thinking their germination moment has arrived (Carroll, 2016; Abhilash, 2016; Hiroyuki, 2014).

The $M$. suriga is a multiuse endemic tree and exploited for various purposes, hence enhancing the seed germination potency is most important for the conservation of this RET species. But the viability of $M$. suriga seeds lasts only for 20 to 30 days during June. In this concern, the experiment was conducted to evaluate the germination potency of the seeds comparatively in the booth in vivo and in vitro conditions.

Phytohormones or plant growth regulators (PGRs) are endogenous substances (chemical) synthesised by the plant for the promotion or inhibition of some metabolic processes within the plants. In a small amount, they modify the natural growth regulatory systems of the plant right from seed germination (i.e., it regulates physiological processes), they can be natural or synthetic; however, they play a central role in morphology and physiology of plants. The major problem noticed in $M$. suriga is the less viability of the seeds, which lasts within two months and hence the in vitro germination is the breakthrough to break the dormancy of the seeds.

The study carried out by us revealed that in in vivo condition the decoated seeds, pre-treated with NAA for $24 \mathrm{~h}$ showed $86 \%$ of germination. In in vitro condition, the seed germination was boosted significantly $(91.67 \%)$ on MS medium supplemented with NAA and TDZ. The decoated seeds grown in in vitro condition have shown increased percent of germination, which may be because of several factors such as, supplemented nutrients, the combination of the auxin and cytokinin, less exposure to the various climatic factors as well as the infections and other barriers, removal of seed coats may helpful in responding to the in vitro growth condition quickly and rapidly. And maybe accredited to the fact that at a supplemented concentration of plant growth regulators, increased the stimulation of the expression of enzymes, affecting both the physiological and metabolical activities within the seeds thereby, promoting embryo growth and reducing the physical restraint imposed by the endosperm or seed testa making way for the protrusion of the radicle. Also, effective in overcoming dormancy, thereby causing rapid germination of seeds (Singh and Murthy, 1987; Jan and Shekhawat, 2011).

Recently Shikhasmita et al., 2016, Chary et al., 2017, and Ajith et al., 2018 have also investigated the breaking of seed dormancy of other various endemic, endangered medicinal plants and succeeded in breaking of seed dormancy by employing various treatments. In M. suriga Rajesh et al., 2011 have reported the germination in intact seeds in relation to the seed size and also the germination of seed on treatment with cow dung slurry.

\section{Micropropagation studies}

Micropropagation is the method of vegetative growth and reproduction plants from, tissues or seeds. It is carried out in aseptic and favourable conditions on growth media, using various plant tissue culture techniques (Fowler et al., 1993; Bhojwani and Razdan, 1996; Zhou and $\mathrm{Wu}, 2006$ ). Tissue culture is based on the theory of totipotency; the ability of plant cells and tissues to develop into a whole new plant (Fowler et al., 1993). Gottlieb Haberlandt (1854-1945), a German botanist is considered as the father of plant tissue culture, was the first to separate and culture plant cells on Knop's salt solution in 1898 (Krikorian and Berquam, 1969). Micropropagation has the potential to provide high multiplication rate of selected tree genotypes. In conservative cultivation, several plants do not sprout, flower and produce seeds under certain climatic situations or have extensive periods of growth and multiplication. Micropropagation insures a good consistent supply of medicinal plants, using minimum space and time (Prakash and Van staden, 2007). From the last few decades, there has been a good increase in research on the medicinal plant. A number of new medicines have been discovered and advancements in production technology to harvest pharmaceutically important metabolites.

About $40 \%$ of compounds used in the pharmaceutical industry are directly or indirectly derived from plants (Stafford, 1986) because the chemical synthesis of such compounds is either not possible and economically not viable (Oksman and Inzé, 2004). Therefore, a huge number of plant species (especially medicinal) are under threat of extinction because of their over-exploitation (Vines, 2004; Rout et al., 2000; Edwards, 2004)

Plant tissue culture studies were carried out for the preservation of medicinal plant resources and efficient production of pharmaceutically important secondary metabolites. Micropropagation methods for M. suriga were established, and these methods enabled much more efficient proliferation of plants than the conventional approaches using seedling or layering. In our study, TDZ was found to be more effective in the induction of multiple shoots as compared to other cytokinins. The synergistic effect of TDZ with other cytokinin/auxin was found more effective than using alone.

\section{Direct organogenesis}

The production of buds or shoots directly from the plant tissue without intervening callus phase is termed as direct organogenesis. Plants have been proliferated by direct organogenesis for better reproduction rates, production of transgenic plants, clonal propagation, and most importantly for the conservation of genetic material of many threatened, endemic and vulnerable medicinal plants. The axillary bud induction or multiple shoot initiation methods are the most common means of micropropagation since it ensures the production of even planting material without genomic variation. Axillary shoots are formed directly from explants, and the chances of the organised shoot meristem undergoing mutation are comparatively low. This technique is referred to as multiple bud induction. Various economically important plants have been propagated using this method.

The in vitro shoot regeneration was achieved directly by culturing cotyledon and hypocotyl explants on MS medium supplemented with combinations of BAP and TDZ without undergoing callogenic phase. In vitro regeneration of plants is influenced by many factors such as environment around cultures, media composition, and source of explant, plant growth hormones and genotype (Zhang, 1998; Bano, 2010; Jana and Shekhawat, 2011; Dhir and Shekhawat, 2014). In our study, high-frequency direct regeneration from cotyledonary explant was achieved at the concentrations of $2 \mathrm{mg} \mathrm{L}^{-1} \mathrm{BAP}$ and $0.2 \mathrm{mg} \mathrm{L}^{-1} \mathrm{TDZ}$ In hypocotyl explant, culture best caulogenic response was observed at the concentration of $3 \mathrm{mg} \mathrm{L}^{-1} \mathrm{BAP}$ and $0.2 \mathrm{mg} \mathrm{L}^{-1} \mathrm{TDZ}$, and the organogenesis of shoots was achieved directly from the nodes and apical region of the hypocotyl explants. 
Many researchers have also reported the regeneration of plantlets from cotyledon explants viz, Sinapis alba (Jain, 1989), P. coccineus L. (Angelini and Allayene, 1989), Ferula ass-foetida L. (Zare et al, 2010), Millettia pinnata (L.) (Nagar et al., 2015), A. melanocarpa, P. communis, and A. mitschurinni (Jonathan et al., 2018), have reported the regeneration of plantlets from cotyledonary explants. Similarly, hypocotyl explants were also used for the organogenesis of shoots, viz. Brassica carinata A. Br. (Yang et al., 1991), Arabidosis thaliana (Gendreau et al., 1997), Brassica napus L. (Tang et al., 2011), Brassica oleracea cv. (Gambhir et al., 2017) Zygophyllum potaninii (Bayarmaa et al., 2018), Solanum quitoense (Gutiérrez et al., 2019).

\section{Indirect organogenesis}

Development of plantlets directly through the callus is called indirect organogenesis. Generation of plantlets using this method ensures mass multiplication and conservation of species and its unique traits.

Since the age of explant is of high paramount importance in tissue culture, the younger explants are more responsive than, the older one. Furthermore sterilisation of younger tissue is easier than the older tissue. Our study, for the first time, indicated the candidature of the leaf explant of $M$. suriga inoculated onto MS medium supplemented with 2,4-D and BAP. The mass of calli turned from whitish to brown, showed differentiation of shoot buds. The well-grown plantlets after rooting stage maintained under culture condition are processed further for primary and secondary hardening. Similarly, regeneration of plantlets from leaf explants of Ficus religiosa (Hesami et al., 2018), Solanum quitoense (Gutiérrez et al., 2019), have been achieved and reported.

The majority of woody plants and some herbaceous species caused browning of the explants and callus, followed by necrosis of cells and causes death (Zhang $\boldsymbol{e}$ al., 1998). The browning of the medium is due to the release of phenol by the explants, which gets oxidised, and this oxidation product could be phytotoxic. Thus, there needs to be a scrutinised investigation before incubating explants in the culture medium (Ko et al., 2009). The degree of browning is different from species to species and depends on the age of the tissue (old tissues show more browning than the younger one), the season of culture initiation (more in winters and autumn), and composition of the medium (Sáenz et al., 2010). Another major drawback is the presence of endophytic contaminants in the woody species, which will interrupt the regeneration process of the explants in in vitro condition.

\section{CONCLUSION}

The role of medicinal plants in pharmaceutics and other industries is strengthening India's economy and cannot exclusively depend on natura botanical sources. The present study was so based \& aimed at the derivation of in vitro regeneration protocol for $M$. suriga. In the present study, we have emphasised the in vitro regeneration protocol to conserve $M$. suriga, which is considered as RET species. This plant is a novel source of phytochemical and the developmental biotechnology has opened up avenues for the propagation of the elite medicinal plant. Further, the derivation of protocol for multiplication using bioreactor method and by using somatic embryos may help in better conservation of this species.

Acknowledgements: The authors are thankful to DBT, New Delhi, India for providing financial support through DBT- BUILDER program (Order No. BT/PR9128/INF/22/190/2013, Dated: 30/06/2015) and the Kuvempu University administrative authority for offering the facility to carry out the work.

\section{REFERENCE}

Abhilasha, R., (2016). Seed Dormancy: Meaning, Methods and Significance, Plant Physiology, Biology discussion.

Ajith, S., Krishna, V., Shastri, S. L. and Ravi, S., (2018). Dormancy breaking of stored seeds of Buchanania lanzan Spreng. - An endangered medicinal plant of the Western Ghats, JETIR, 5, 237-243.

Angelini, R. R. and Allavena, A., (1989). Plant regeneration from immature cotyledon explant cultures of bean (P. coccineus L.), Plant Cell Tiss Organ Cult, 19, 167. https://doi.org/10.1007/BF00035816.

Ankur, Patwardhan, and R. Vasudeva, (2003). Conservation and Promotion of Endangered Medicinal Plant Species from Western Ghats of India.

Bano, R., Khan, M. H., (2010). Khan R S, Rashid H and Swat Z A, Development of an efficient regeneration protocol for three genotypes of Brassica juncea Pakistan Journal of Botany, 42, 963-969.

Bayarmaa, G. A., Lee, N. N., Kang, H. D., (2018). Micropropagation of the Mongolian medicinal plant Zygophyllum potaninii via somatic embryogenesis, Plant Biotechnol Rep., 12, 187. https://doi.org/10.1007/s11816-018-0484-9.

Bhojwani, S. S. and Razdan, M. K., (1996). Plant tissue culture: Theory and Practice: Developments in crop science, 5, Elsevier, Amsterdam. ISBN: 9780080539096.

Carroll, Jackie. (n.d.). Methods to Break Seed Dormancy. Home Guides | SF Gate. Retrieved from http://homeguides.sfgate.com/methods-break-seeddormancy-73304.html.
Chary, Srinivasa, Kulkarni, Rengasamy, M. V., Kannan and Staden, V. J., (2017). Seed germination and seedling growth of Bauhinia variegata in response to smoke-water and synthesised smoke-isolated karrikinolide (KAR1). Seed Science and Technology, 45. https://doi.org/10.15258/sst.2017.45.2.19.

Chopra, R. N., (1956). Glossary of Indian Medicinal Plants, Council of Scientific and Industrial Research, New Delhi, 174.

Çördük, N., Aki, C., (2011). Inhibition of browning problem during micropropagation of Sideritis trojana bornm., an endemic medicinal herb of Turkey, Rom Biotech. Lett. 16, 6761-6765.

Dhir, R., Shekhawat, G. S., (2014). In vitro propagation using transverse thin cell layer culture and homogeneity assessment in Ceropegia bulbosa Roxb. Journa of Plant Growth Regulations, 33, 820-830. https://doi.org/10.1007/s00344-0149432-2.

Edwards, R., (2004). No remedy in sight for herbal ransack, New Scientist, 181, 10-11.

Fowler, M. R., Rayns, F. W. and Hunter, C. F., 1993. The language and aims of plant cell and tissue culture in vitro, Butterworth-Heinemann Ltd, Oxford, 1-18.

Gambhir, G., Kumar, P., \& Srivastava, D. K. (2017). High frequency regeneration of plants from cotyledon and hypocotyl cultures in Brassica oleracea cv. Pride of India. Biotechnology reports (Amsterdam, Netherlands), 15 107-113. 10.1016/i.btre.2017.02.005.

Gendreau, E., Traas, J., Desnos, T., Grandjean, O., Caboche, M. and Hofte, H., (1997). Cellular Basis of Hypocotyl Growth in Arabidopsis thaliana, Plant Physiology, 114 (1), 295-305. https://doi.org/10.1104/pp.114.1.295.

Gutiérrez, Bernardo, Cobo, M. M., Orellana, M., Vega, J., Arahana, V. Jaramillo, V. and Torres, M. D., (2019). Micropropagation of Solanum quitoense var. quitoense by apical bud, petiole and hypocotyl culture, Plant Biotechnology, 19- 0317. 10.5511/plantbiotechnology.19.0317a.

Hassan, B., (2012). Medicinal Plants (Importance and Uses), Pharmaceutica Analytica Acta, 03, (10), 4172.

Hesami, Mohsen and Mohammad, Hosein, Daneshvar, (2018). Indirect Organogenesis through Seedling-Derived Leaf Segments of Ficus Religiosa - a Multipurpose Woody Medicinal Plant, Journal of Crop Science and Biotechnology, 21, 129-136. https://doi.org/10.1007/s12892-018-0024-0.

Hiroyuki, N., (2014). Seed dormancy and germination-emerging mechanisms and new hypotheses. Frontiers in Plant Science, 5, 233 https://doi.org/10.3389/fpls.2014.00233.

Jain, R. K., Brune, U. and Friedt, W., (1989). Plant regeneration from in vitro cultures of cotyledon explants and anthers of Sinapis alba and its implications on breeding of crucifers, Euphytica, 43, 153. https://doi.org/10.1007/BF00037908.

Jana, S., Shekhawat, G. S., (2011). Plant growth regulators, adenine sulphate and carbohydrates regulate organogenesis and in vitro flowering of Anethum graveolens, Acta Physiologiae Plantarum, 33, 305-311. https://doi.org/10.1007/s11738-010-0548-0.

Jonathan, D., Mahoney, Peter, V., Apicella, Mark., H. Brand, (2018). Adventitious shoot regeneration from in vitro leaves of Aronia mitschurinii and cotyledons of closely related Pyrinae taxa, Scientia Horticulturae, 237, 135-141. https://doi.org/10.1016/j.scienta.2018.03.062.

Ko, W., Su, C., Chen, C., Chao, C., (2009). Control of lethal browning of tissue culture plantlets of Cavendish banana cv. Formosana with ascorbic acid, Plant Cell Tissue Organ Cult, 96, 137-141. https://doi.org/10.1007/s11240-008-9469-7. Krikorian, A. D. and D. L. Berquam, (1969). Plant cell and tissue cultures: The role of Haberlandt. The Botanical Review, 35, 59-67. https://doi.org/10.1007/9783-7091-6040-4_2.

Nagar, D. S., Jha, S. K., Jani, J., (2015). Direct adventitious shoot bud formation on hypocotyls explants in Millettia pinnata (L.) Panigrahi-a biodiesel producing medicinal tree species. Physiology and Molecular Biology of Plants, 21, 287-292. https://doi.org/10.1007/s12298-015-0293-3.

Nath, Shikhasmita and Nath, Arun, Das, Ashesh, (2016). Seed Germination in Barringtonia acutangula: A Floodplain Tree from North East India, International Journal of Ecology and Environmental Sciences, 42, 47-53.

Oksman-Caldentey, K. M. and Inzé, D., (2004). Plant cell factories in the postgenomic era: new ways to produce designer secondary metabolites, Trends in Plant Science, 9, 433-440. https://doi.org/10.1016/j.tplants.2004.07.006.

Oluwakemi, A. B., Edward, B. E. and Olawole, O. O., (2018). IOP Conf. Series: Earth and Environmental Science.

Pradeepa, K., (2016). Comparative screening of phytoconstituents of leaves, stem bark and their calli and evaluation of pharmacological properties of Delonix elata.

Prakash, S. and J. Van, Staden, (2007). Micropropagation of Hoslundia opposita Vahl-a valuable medicinal plant, South African Journal of Botany, 73, 60-63. https://doi.org/10.1016/j.sajb.2006.07.001.

Prusti, A. B. and Behera, K. K., (2007). Ethnobotanical Exploration of Malkangiri District of Orissa, India, Ethnobotanical Leaflets, 1, 14

Pullaiah, T., (2006). Encyclopaedia of World Medicinal Plants, Regency Publication, New Delhi, India, 421.

Rajesh, P. G., (2011). Influence of seed size on germination and seedling growth in Mammea suriga Karnataka, J. Agric. Sci. 24:3, 415 - 416. 
Rout, G. R., Samantaray, S. and Das. (2000). In vitro manipulation and propagation of medicinal plants, Biotechnology Advances, 18, 91-120. https://doi.org/10.1016/S0734-9750(99)00026-9.

Sáenz, L., Herrera-Herrera, G., Uicab-Ballote, F., Chan, J. L., Oropeza, C., (2010). Influence of form of activated charcoal on embryogenic callus formation in coconut (Cocos nucifera), Plant Cell Tissue Organ Cult, 100, 301-308. https://doi.org/10.1007/s11240-009-9651-6.

Santhosh, Kumar, S. R., (2018). Micropropagation studies screening of phytochemical constituents and evaluation of pharmacological activities of Caesalpinia Bonducella L Roxb.

Sigma protocol, 1999. Explant Sterilization - Plant Tissue Culture Protocol.

Singh, C. and Murthy, Y. S., (1987). Effect of some growth regulators on the seed germination and seedling growth of Cassia obtusifolia, Acta Botanica Indica, 15, 77-79.

Smita, S. Kubal, Vaibhavi, S. Shirke, K. K. Shirke,Wanage, S. S., Rajesh, P Gunaga, and A. D. Rane, (2013). Triple-seeds in Mammea suriga (Buch. -Ham. Ex Roxb.), an Avenue Tree, Research and Reviews: Journal of Botanical Sciences, 2, 1-2

Stafford, A., Morris, P. and Flower, M. W., (1986). Fowler Plant cell biotechnology, A perspective. Enzyme and Microbial Technology, 8, 578-587. https://doi.org/10.1016/0141-0229(86)90114-6.

Tang, G. X., Knecht, K., Yang, X. F., (2011). A two-step protocol for shoot regeneration from hypocotyl explants of oilseed rape and its application for Agrobacterium-mediated transformation, Biol Plant. 55, 21. https://doi.org/10.1007/s10535-011-0003-0.

Valsaraj, R., Pushpangadan, P., Nyman, U., Smitt, U. V., Adsersen, A., and Guditsen, L., (1995), New antimalarial drugs from Indian medicinal plants. International Seminar on Recent Trends in Pharmaceutical Sciences, Oatacamund Abstract, No. 2A, 18-20.

Venkatesh, A., (2017). Proteomic approach to identify defense related proteins in Musa accumineta var. puttabale challenged with fusarium oxysporum f. sp. Cubiense.

Vines, G., (2004). Herbal Harvest with future: towards sustainable source for medicinal plants. Plant life International.

Yang, M., Jia, S. and Pua, E., (1991). High frequency of plant regeneration from hypocotyl explants of Brassica carinata A. Br, Plant Cell, Tissue and Organ Culture, 24, 79-82. https://doi.org/10.1007/BF00039734.

Yen, Y. and Hain, P., (2012). Basic Techniques of Plant Tissue Cultures.

Zare, A.R., Solouki, M., \& Omidi, M. (2010). Callus induction and plant regeneration in Ferula assa foetida L. (Asafetida), an endangered medicinal plant. Zhang, F. L., Takahata, Y., Xu, J. B., (1998). Medium and genotype factors influencing the regeneration from cotyledonary explants of Chinese cabbage (Brassica compestris L. S sp Pekinensis), Plant Cell Reports, 17, 780-786. https://doi.org/10.1007/s002990050482.

Zhou, L. G. and Wu, J. Y., (2006). Development and Application of Medicinal Plant Tissue Cultures for Production of Drugs and Herbal Medicinals in China, Natural Product Reports, 23, 789-810. https://doi.org/10.1039/B610767B. 